Epidemiology and Psychiatric

Sciences

cambridge.org/eps

\section{Contemporary Outsider Art}

This Section of Epidemiology and Psychiatric Sciences appears in each issue of the Journal and is dedicated to all forms of creative production born of an intimate and individual urge, often secretive, unbound from the conventional art system rules. Through short descriptions of the Outsider art work of prominent artists and new protagonists often hosted in community mental health services, this Section intends to investigate the latest developments of the contemporary art scene, where the distances between the edge and the center are becoming more and more vague.

Carole Tansella, Section Editor

Cite this article: Fróis JP (2020). The uncanny drawings of a 10-year-old Portuguese boy. Epidemiology and Psychiatric Sciences 29, e106, 1-2. https://doi.org/10.1017/ S2045796020000177

Received: 12 January 2020

Accepted: 21 January 2020

Key words:

Art; art brut; child psychiatry; psychosis

Author for correspondence:

J. P. Fróis, E-mail: simurg@mail.telepac.pt

(c) The Author(s), 2020. This is an Open Access article, distributed under the terms of the Creative Commons Attribution licence (http:// creativecommons.org/licenses/by/4.0/), which permits unrestricted re-use, distribution, and reproduction in any medium, provided the original work is properly cited.

\section{CAMBRIDGE UNIVERSITY PRESS}

\title{
The uncanny drawings of a 10-year-old Portuguese boy
}

\section{J. P. Fróis (iD)}

Center for Phenomenological Psychology and Aesthetics, CPPA, University of Copenhagen, Denmark

\begin{abstract}
The child's drawing is not an image but a sign, and as a sign it is situated in the pictographic domain and not
\end{abstract} in the representative one: in the domain of writing and not in that of painting.

Cesare Brandi, 1960

Art works created by the mentally ill spring from the same basic psychological roots as do the works of other artists.

Rudolf Arnheim, 1986

The science of the late 19th century profoundly influenced the way we understand children and the various dimensions of their intellectual and emotional development. One of these dimensions includes children's artistic creative urge as manifested in children's art productions. Child art has fascinated artists and scientists of all time. The English naturalist Charles Darwin included the analysis of his children's graphic productions in his studies. James Sully, in the context of the 'Child Study Movement', understood children's drawings as part of an evolutionary process developed step by step, by 'discrete phases'. It was up to Italian archaeologist and art historian Corrado Ricci to publish the first full treatise on children's drawings, named L'Arte dei Bambini (1887), although earlier studies by Töpffer (1848) and Ruskin (1857) had alluded to the topic. The early years of the 20th century were decisive in generating artistic, anthropological, psychological and pedagogical knowledge of child art: members of all those scientific areas have established multiple correlations between children's drawings, the productions of remote tribes and those of the mentally ill (Boas, 1966; Peiry, 2016). Several collections of children's drawings and paintings became available and inspired such well-known artists as Jean Dubuffet, Paul Klee and Gabriele Münter. However, studies of drawings made by children with special educational needs are still relatively rare as compared to those made by other children (Selfe, 1977; Fineberg, 1997).

In the archives of the Medical School of the University of Lisbon there is a unique collection of crayon and watercolour drawings made by children of different ages who were being observed at the Pedagogical Medical Institute in Lisbon in the forties and fifties of the 20th century. According to the director of this Institute, Vítor Fontes (1893-1979), a prominent anatomist and psychiatrist, the medical-pedagogical approach had to be 'the application of medical knowledge to the treatment of the individual with psychic or organic disability; a treatment which involves, in addition to other therapeutic means and in a more essential way, the pedagogical ones' (Fontes, 1939). For the Institute's doctors, the patient's drawings helped to clarify the diagnosis of psychiatric disorders, whether in children or adults. The collection of 200 works by Fontes comes from a set of 30.000 existing works at the Institute and was for the first time shown at the 'Scientific Exhibition of the 10th World Congress of Pediatrics' (held in Lisbon, 1962). From this set of drawings, one drawing connected with a detailed description resulting from the clinical observation of a 10-year-old boy, specifically draws our attention. The original of the drawing (Fig. 1) is part of the collection mentioned before and the other one (Fig. 2) was reproduced in the article 'A Case of Very Early Dementia' published in the magazine The Portuguese Child (1942), along with 30 other drawings. The author of the drawings 'rarely looked at people when he spoke, usually bowed his head, covered his ears with his hands and only then responded. In a nutshell, strange attitudes were noticed from the age of nine and a half years. A measles attack was followed by a major inflammation of the genitals (...) During the examination there were various stereotyped movements, sometimes with the upper limbs, sometimes shaking the body or the head' (Fontes, 1942, p. 165, p. 166). The boy attended school from 7 to 9 years with moderate results. In his article, Fontes wrote that this was a case of the 'schizophrenic syndrome' and discussed the concept of 'early dementia' relying on the contributions of the Italian psychiatrist Sante De Sanctis (1862-1935) to the then emerging field of child psychiatry. For De Sanctis (1925) this type of dementia was a kind of 'regression of the mental faculties'.

During his month-long stay at the Institute, the boy made 100 free drawings. All of the drawings that I have seen seem to fall outside the range of the standard drawings typical of children of that age, both what regards their meaning and their form. On the first day of 


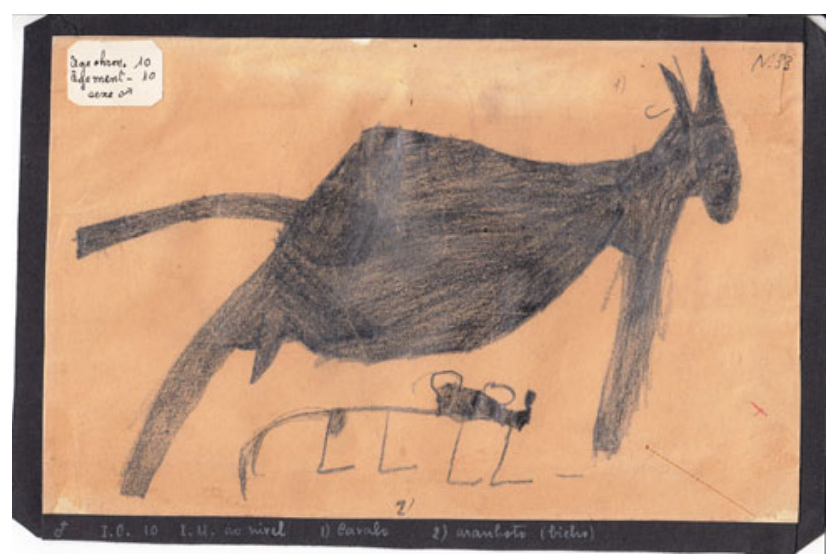

Fig. 1. Zoomorphic drawings. Donkey and small beast, July 1942, Graphite pencil, $22 \mathrm{~cm} \times 14 \mathrm{~cm}$. Collection of the Institute of Anatomy, Lisbon School of Medicine, University of Lisbon.

his stay the boy drew an awkward picture of a man with arms and legs sticking out of a trunk (Fontes, 1942). Fontes classified the set of drawings into two broad categories: in the first category he included anthropomorphic drawings with a 'vesanic' appearance. They were like the drawings made by the 'asylum freaks', with explicit sexual signs, i.e. graphically strange human figures where the schematic character stands out (the boy referred to them as 'skeletons') and in the second category he included zoomorphic drawings that also have sexual content.

The two drawings shown here emerge with a well-defined contour. According to their author, they are 'donkeys' and as such they belong to the second category of drawings called zoomorphic by Fontes. In both of them the genital organ is patent and in one drawing the genital organ produces some sort of balls or drops reminding the act of urinating. In the drawing on the left there are two figures filled with graffiti of which the smallest according to the boy is a 'small beast'. The drawing has a caption with the boy's chronological and mental age. In the drawing on the right (Fig. 2), with a precise contour, transparency as representation technique is deliberately used. Inside the larger figure (body) where a well-defined eye scheme appears, we find another figure that repeats the larger one. The small inner figure is surrounded by circular (spiraled) elements. By their graphic appearance the two drawings remind us of the (prehistoric) representations found in caves and they reveal the child's exceptional capacity to depict the total object within a peculiar syncretic vision. As a result, they strike us as truly mysterious.

Acknowledgements. The author is especially grateful to the Medical School of Lisbon University. Thanks are due to the Dean of the Medical School, Prof. Dr Fausto J. Pinto, and to the head of its Institute of Anatomy, Prof. Dr A J. Gonçalves Ferreira, for providing the permission to reproduce

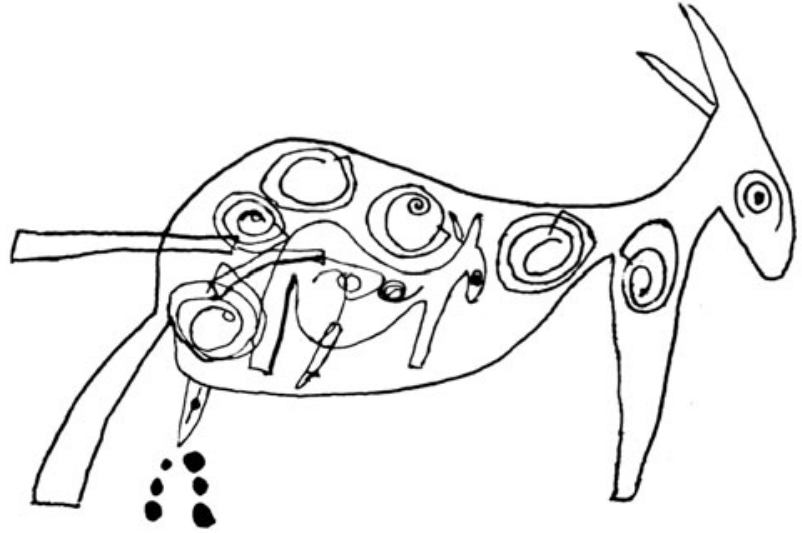

Fig. 2. Zoomorphic drawing. Donkey, Graphite pencil, $22 \mathrm{~cm} \times 14 \mathrm{~cm}$, In Vítor Fontes, Um caso de demência precocíssima, A Criança Portuguesa, Boletim do Instituto Aurélio da Costa Ferreira, 1, 1942, p.175.

the drawings for this article. I'm especially thankful to Pedro Henriques, the person who found the lost collection of children's drawings at the Institute of Anatomy. I extend my acknowledgments to Isabel Cameirinha and Lurdes Barata from the library-archive of the Medical School for the assistance in this research. I would also like to thank Professor René van der Veer for the revision of the article as well as his comments on the manuscript.

About the author. João Pedro Fróis is a University Professor and Researcher. His main interests lie in the Psychology of Visual Arts, Empirical Aesthetics and the Philosophy and History of Art Education. He has published articles in several journals on the Psychology of the Visual Arts. He has worked as a Rehabilitation Psychologist for more than a decade. As from 2014, he has been a Fellow of the International Association of Empirical Aesthetics. Research Associate of the Center for Phenomenological Psychology and Aesthetics - CPPA, Department of Psychology, University of Copenhagen.

Carole Tansella, Section Editor

\section{References}

Arnheim R (1986) The artistry of psychotics. American Scientist 74, 48-54. Boas G (1966) The Cult of Childhood. Dallas, Texas: Spring Publications. Brandi C $(1960,2001)$ Segno e Imagine (Disegno Infantile e Raffigurazioni Preistoriche, pp. 18-30). Palermo: Aesthetica Edizioni.

De Santis S (1925) Neuropsichiatria infantile: patologia e diagnostic. Roma: Stock. Fineberg J (1997) The Innocent Eye. New Jersey: Princeton University Press. Fontes V (1939) Médico-Pedagogia. Clínica, Higiene e Hidrologia 5, 111-114.

Fontes V (1942) Um caso de demência precocíssima, A Criança Portuguesa, Boletim do Instituto António Aurélio da Costa Ferreira,1, pp. 161-185.

Peiry L (2016) L'Art Brut. Paris: Flammarion.

Ruskin J (1857) The Elements of Drawing. London: Smith, Elder and Co.

Selfe L (1977) Nadia: A Case of Extraordinary Drawing Ability in an Autistic Child. London: Academic Press.

Töpffer R (1848) Réflexions et Menus Propos d'un Peintre Genevois ou Essai sur le Beau dans les Arts (1848). Paris: Hachette. 